\title{
Extent of Academic Achievement of Day and Boarding Secondary Schools Students in Anambra State, Nigeria.
}

\author{
Dr Okoye Faith Ogechukwu, Nnamani Patience Chika \\ Department of Educational Management and Policy \\ Nnamdi Azikiwe University, Awka. \\ Department of Educational Management and Policy \\ Nnamdi Azikiwe University, Awka
}

\begin{abstract}
The study examined the extent of Academic Achievement of Day and Boarding Secondary Schools Students in Onitsha Education Zone of Anambra State. Three research questions guided the study and survey research design was adopted. Descriptive survey research design was used for the study. The population of the study consisted 850 teachers within Onitsha Education Zone in Anambra State. The sample size consisted 85 teachers and was selected using simple random sampling. The instrument used for data collection was questionnaire and the data collected were analyzed with mean. The findings revealed that boarding students academically achieve better than day students and that day students are distracted at home unlike boarding school students who are under the control of teachers for their study. It was concluded that lack of finance, educational facilities and inadequate infrastructures are the factors that affect the academic achievement of both the day and boarding students. The researchers recommended among others that students should be allowed to attend boarding schools so as to perform better and that government should intervene in schools by providing them with academic and boarding facilities.
\end{abstract}

Keywords: Education, academic achievement, secondary school.

\section{Introduction}

Informal education is as old as human race in the globe. Education system at this period was purely traditional and informal in nature. However, formal system of education can be traced back to the ancient Greek system of education in Athens, where the young boys were sent to institutes to be trained as brave soldiers (Adetunde and Asare 2009). In a similar development, they categorically stated that "looking back to our traditional society, apprentices were sent to stay with their apprenticeship so as to be near their source of knowledge".

Prior to formal education in Nigeria was the indigenous system of education which recorded informal and semi formal type of education system. The advent of formal education with boarding facilities in Nigeria can be traced to the coming of Christian Missionary Society (CMS) as far back as 1840s. It was then used to seclude the converts especially the young ones from the larger society to enable the missionaries inculcate Christian as well as western values and culture into the mindset of the school children. The idea behind this was that, if the school children lived in a mission-controlled environment, it would be easier to indoctrinate and encourage them to attend school regularly. According to Collins and Check (1999), the main objectives of the boarding house system are as follows:

a) The provision of opportunities for students of varying social and economic background to live together and share common problems and interest.

b) The provision of opportunities for students to develop independence and a sense of responsibility.

c) The provision of stable environment with regular sleep, planned diet and conducive atmosphere, which encourages serious academic work.

d)The provision of opportunities for students to make genuine friendship in life. 
e) The provision of boarding facilities for students whose parents live very far from school.

The boarding system however, is a matter of choice for those who can afford the cost. For others they may prefer coming to school from home since they cannot afford it. On daily basis, significant population of secondary school students in Onitsha education zone embarks on their education programme as day students, the attendant challenges notwithstanding. There have been speculations on whether the boarding school is really necessary (Adeniran, 1997). Some parents residing within the study area due to many reasons enroll their wards as day students rather than boarders. Noticeably, these students are seemingly/faced with myriad distractions from their academic pursuit after school periods.

According, to Aremu (2002) boarding schools help in the great achievement of academic performance since it gives the students the necessary time to attend to their studies and deprive them a homely distraction that normally disturb the students from studying hard. However, some Nigerians have started to question the wisdom of spending the government limited resources for the provision of boarding facilities when such resources could be used to provide more schools (Aremu, 2002).

Academic achievement of students especially at the secondary school level is not only a pointer to the effectiveness or otherwise of schools but a major determinant of the future of youths in particular and the nation in general. The medium through which the attainment of individuals and the nation's educational goals can be achieved is learning (Sokan, 2002). Obviously, learning and academic achievement do not thrive in a situation devoid of enabling environment. This scenario brings to fore the import of boarding school where the students may be less distracted by household chores.

Secondary Education according to Federal Republic of Nigeria (2004) is the education children receive after primary education and before the tertiary stage. The two broad goals of secondary education shall be to prepare the individual for:

a) Useful living within the society; and

b) Higher education.

As a result of the yearning for credible education in Nigeria, came the revision of 2004 National Policy Education (NPE) which metamorphosed into the latest 2013 edition as approved by National Education Research Development Committee (NERDC). In the Federal Republic of Nigeria (FRN) (2013, 6th edition), Secondary education encompassed

a) Junior secondary education;

Post-Basic Education and Career Development (PBECD): a type of education that children receive after a successful completion of ten years basic education and passing the Basic Education Certificate Examination (BECE) and Junior Arabic and Islamic Studies Certificate Examination (JAISCE). It includes (i) senior secondary education,(ii) higher school, and (iii) continuing education given in Vocational Enterprise Institutions (VEIs). In Nigerian system of education, it is at secondary level that boarding system of education is inculcated. Seemingly, many stakeholders in education have appeared to allude that poor academic achievement of secondary school students may be as a result of inadequate funding and poor boarding facilities. Hence, some analysts listed lack of boarding facilities as one of the factors responsible for the falling standard of the nation's education system (Oyeniyi, 2010). Hence, the big question of whether boarding school students achieve better than day students come to bare. It is therefore, in the light of this thought that the researchers were spurred to embark on the study which investigated the extent of academic achievement of day and boarding secondary school students in Anambra state.

\section{Statement of the Problem}

The question of whether more boarding facilities should be provided for our secondary schools or not has in recent times engaged the attention of the government as well as educators and parents alike. The federal as well as state government found it increasingly difficult to provide enough secondary schools with boarding facilities for the ever-increasing population of students. This is an issue, which no responsible government can afford to toy with. Even though more secondary schools have been established throughout the country by private individuals and religious organizations, there seem to be inadequate boarding facilities for majority of these schools. 
Varied opinions are also held by different individuals on the academic achievement of day and boarding students in Onitsha education zone, Anambra state. Also the problem of inadequate provisions of boarding facilities like chairs, reading tables, spacious class room, water, bed and other teaching facilities appear to have been a great challenge to the academic achievement of students in the study area. In addition, the inadequate provision of electricity supply and balanced diet by the boarding schools seemingly retard the academic achievement of students. It appears that economic status of many parents seem to determine their wards enrolment in boarding schools in Anambra state. Apparently, low income parents preferably engage their wards as day students in secondary schools. All these and more prompted the researchers to investigate the extent of academic achievements of day and boarding secondary school students in Onitsha Education Zone of Anambra State.

\section{Research Questions}

The following research questions guided the study:

1. To what extent are the academic achievements of boarding school students differ from the day school students?

2. To what extent do environmental factors affect academic achievement of both the day and the boarding students?

3. What are the challenges that hinder the development of the boarding and day schools?

4. What are the possible solutions to the challenges of development of boarding schools?

\section{Method}

Descriptive survey design was adopted for the research. The population of the study comprised 850 teachers from six secondary schools in Onitsha South Local Government Area of Anambra State. The sample for the study was 85 teachers. The instrument for data collection was a 25 item questionnaire. The instrument was validated by three experts, one in Measurement and Evaluation and two in Educational Management and Policy Department, Nnamdi Azikiwe University, Awka. The reliability of the instrument was determined using Cronbach Alpha method and the value was 0.87, this was considered adequate. The data collected were analyzed with simple percentile and mean to answer the research questions. Any mean score of 2.50 and above is considered accepted whereas any mean score less than 2.50 is not accepted.

\section{Results}

\section{Research Question 1}

To what extent are the academic achievements of boarding school students differ from day school students.

Table 1: Mean ratings on how academic achievements of boarding school students differ from day students of secondary schools.

\begin{tabular}{llll}
\hline S/n & $\begin{array}{l}\text { Academic achievement of boarding school students differ } \\
\text { from day school students of secondary schools. }\end{array}$ & & Remark \\
\hline 1. & $\begin{array}{l}\text { Boarding schools students perform better in external exams than } \\
\text { day students. }\end{array}$ & 3.2 & $\mathrm{HE}$ \\
2. Boarding school students study more than day school students. & 3.6 & $\mathrm{HE}$ \\
3. Day school students are distracted at home unlike boarding & 4.1 & $\mathrm{VHE}$ \\
4. $\begin{array}{l}\text { Boarding school students are under the control of their teachers } \\
\text { for their study. }\end{array}$ & 4.4 & $\mathrm{VHE}$ \\
5. Boarding school students come to school early than day school & 4.6 & $\mathrm{VHE}$ \\
students. & & \\
Boarding school students are not delayed by traffic jam while & 4.7 & $\mathrm{VHE}$ \\
\hline
\end{tabular}

KEYS: VHE: very high extent. HE: high extent. LE: low extent. VLE: very low extent.

From the analysis above, it shows that the respondents agree to a high extent that boarding students perform better in external exams than day students and that boarding students study more than day school students 
with mean scores of 3.2 and 3.6 respectively. The respondents also agree to a very high extent that day students are distracted at home unlike boarding school students, that boarding students are under the control of their teachers and as such are kept under control for their study, also agree to a very high extent that boarding students come to school early than day school students and also that boarding students are not delayed by traffic jam of any kind with mean scores of 4.1, 4.4, 4.6 and 4.7 respectively.

Research Question 2: To what extent do environmental factors affect academic achievement of both the day and boarding students?

Table 2: Mean ratings on environmental factors that affect academic achieve of both the day and boarding students?

\begin{tabular}{rlcc}
\hline S/n & Extent environmental factors affect academic achievement & $\overline{\mathbf{X}}$ & \multicolumn{2}{c}{ Remark } \\
\hline 7. & Lack of finance for enabling school environment affect day and & 4.3 & VHE \\
& boarding school students. & 3.2 & HE \\
8. & Distance to school affects day schools students. & 4.1 & VHE \\
9. & Dearth of educational facilities. & 4.0 & VHE \\
10. & Inadequate infrastructures. & \\
\hline
\end{tabular}

From the analysis above, it shows that the respondents agree to a very high extent that lack of finance for enabling school environment, dearth of educational facilities and inadequate infrastructures affect the academic achievement of both the day and boarding students with mean scores of $4.3,4.1$ and 4.0 respectively. The respondents also agree to a high extent that distance to school affects day students with a mean score of 3.2 .

Research Question 3: What are the challenges that hinder the development of boarding schools?

Table 3: Mean ratings on challenges that hinder the development of boarding schools?

\begin{tabular}{cllll}
\hline S/n & Challenges that hinder the development of boarding & \multicolumn{3}{c}{ Remark } \\
& schools. & $\mathbf{X}$ & \\
\hline 11. & Lack of government intervention. & 2.7 & $\mathrm{HE}$ \\
12. & Bad road network. & 2.9 & $\mathrm{HE}$ \\
13. & Lack of transportation. & 3.4 & $\mathrm{HE}$ \\
14. & Lack of boarding facilities. & 4.1 & $\mathrm{VHE}$ \\
15. & Inadequate infrastructures. & 4.5 & $\mathrm{VHE}$ \\
16. & Lack of qualified teachers. & 4.6 & $\mathrm{VHE}$ \\
17. & Lack of regular power supply & 3.0 & $\mathrm{HE}$ \\
\hline
\end{tabular}

The analysis on table 3 shows that respondents agree to a high extent that lack of government intervention, bad road network, lack of transportation and regular power supply are the challenges that hinder the development of boarding schools with mean scores of 2.7, 2.9, 3.4 and 3.0 respectively. The respondents also agree to a very high extent that lack of boarding facilities, inadequate infrastructures and lack of qualified teachers are the challenges that hinder the development of boarding schools with mean scores of 4.1, 4.5 and 4.6 respectively.

Research Question 4: What are the possible solutions to the challenges of development of boarding schools? 
Table 4: Mean ratings on possible solutions to challenges that hinder the development of boarding schools?

\begin{tabular}{|c|c|c|c|}
\hline $\mathbf{S} / \mathbf{n}$ & $\begin{array}{l}\text { Possible solutions to challenges that hinder the } \\
\text { development of boarding schools. }\end{array}$ & $\overline{\mathbf{X}}$ & Remark \\
\hline 18. & Provision of adequate finance. & 4.7 & VHE \\
\hline 19. & Governmental intervention. & 4.1 & VHE \\
\hline 20. & Provision of qualified teacher. & 4.3 & VHE \\
\hline 21. & Regular power supply. & 4.0 & VHE \\
\hline 22. & Good road network. & 3.9 & $\mathrm{HE}$ \\
\hline 23. & Efficient transportation. & 4.1 & VHE \\
\hline 24. & Provision of educational facilities. & 4.0 & VHE \\
\hline 25. & Adequate infrastructures. & 4.7 & VHE \\
\hline
\end{tabular}

The analysis shows that the respondents agree to very high extent that provision of adequate finance, qualified teacher, governmental intervention, regular power supply, efficient transportation, provision of educational facilities and adequate infrastructures are the possible solutions to challenges that hinder the development of boarding schools with mean ratings of 4.7, 4.1, 4.3, 4.0, 4.1, 4.0 and 4.7 respectively. The respondents also agree to a high extent that the challenge of good road network hinder the development of boarding schools with a mean score of 3.9 respectively.

\section{Discussion}

From the findings and analyses given in the tables, it is evident that boarding students perform better in examinations than day students. The low academic achievement of day secondary school students indicated in this research corroborated with the findings of Onipede (2003) who gave reasons for such low achievement of day students in public examination to include adolescent experience and lack of knowledge of the subject such as English language, mathematics and sciences.

The scenario whereby some day students attend school very late when may be English and Mathematics lessons have gone lay credence to the beginning of poor academic achievement. Knowledge of a subject definitely begins with participation, attentiveness to the lessons and learning experiences. The aftermath furthermore resulted to the problems of failure which invariably contributed a lot to the moral decadence of adolescents and even increased dropout rate amongst secondary school day students.

The findings of this study attributed poor students achievement to inadequate infrastructure and dearth of educational facilities in secondary schools. Similarly, Adeyemi (2007) opined that poor or decline in students performance in SSCE examinations in other states of the country would be attributed to the inadequacy of facilities in schools. When there is dearth of educational provisions for secondary school day and boarding students, impending failure in examination bedevil all efforts towards credible education and realization of the educational objectives. If nothing is done by the government to achieve the secondary education aspirations enshrined in the philosophy of Nigerian education, hardly will the students be eligible for admission into tertiary education and be useful citizens of this nation which are the two main objectives of secondary education in Nigeria (NPE, 2004). Also, the result shows that boarding students to a high extent study more than day students who are distracted at home by household chores. (Bard, 2011) corroborates with the view point when he opined that day students are distracted at home unlike boarding students that are under control of their teachers and as such are kept in control during their studies.

Concurring, Douglas (2000) opined that, every child must become fully competent in reading to succeed in school and discharge responsibilities as a citizen of a democratic society. Furthermore he stated that without reading a student or learner cannot make meaningful progress in his or her academic pursuit.

In view of the foregoing, the home front seriously poses challenges to the academic achievement of day students, for hardly do some parents imbibe reading culture, provide enabling environment for studies, opportunity for siesta after school periods among others for their wards. Consequently, Okebukola (2004) affirms that, through reading, humans have the tools to transmit knowledge to each succeeding generation. In many families many factors combine to erode enabling environment geared towards academic 
achievement of day students. Unless parents are conversant with the dastardly effects of the situation, day students must be educationally disadvantaged. Any child who fails to read and not studious would not retain the learning experiences transmitted by the teacher. Accordingly, when the necessary knowledge tools are lacking, academic achievements are impaired, hence no knowledge retention for posterity.

Concerning how environmental factors affect academic achievement of both day and boarding students, the study found that underfunding to a very great extent deter students achievement since the enabling environment is lacking, and dearth of educational facilities encumber the efforts of attainment of the desired objectives of education. Inference could be drawn from the English adage that says that mean environment beget mean children. The resultant effect of underfunding that beget mean environment jeopardizes efforts towards academic achievement of both day and boarding students in secondary schools. Thus, when there is repeated poor achievement, unhealthy attitudes and dropouts due to frustration may ensue.

In order to ameliorate the attendant problems hindering academic achievements of day and boarding students, the study suggested adequate funding, provision of qualified teachers, educational facilities, efficient transportation, good road network, regular power supply among others.

An evaluation of the findings depicts that the objectives of the secondary education in Onitsha education zone, Anambra state could be inferred as below expectation giving the fact day students encounter numerous distractions from the home that encumber their desirable efforts for credible academic achievement. Note that FRN (2013) postulates that all Nigerian children should be given equal educational opportunities, yet the scenario in the study area do not reflect this postulation.

\section{Conclusion}

Considering the findings of this research, it is noteworthy that secondary school boarding students in Onitsha education zone achieve better academically than their day counterparts. The findings made the researchers to categorically state that the three tiers of government, stakeholders and parents must contribute to desirable efforts towards what will engender credible students academic achievement. Any venture devoid of this stance will mar the efforts of achievement and realization of the objectives of secondary education in Nigeria.

\section{Recommendations}

Based on the findings of the study, the following recommendations were made:

1. Result oriented secondary education must be solidly funded through quality boarding facilities.

2. The ministry of education must regularly monitor, evaluate and supervise the teaching, learning experiences and boarding facilities for Nigerian secondary education.

3. Irrespective of the economic recession in the country, parents should strive to provide the needed educational facilities for their wards credible secondary education via boarding schooling.

\section{References}

1. Adetunde, A.I. and Asare, B. (2001). Comparative performance of day and boarding students in secondary school certificate mathematics examinations: A case study of Kasena-Nankana and Asuogyaman Districts of Ghana. Academic Arena, 2009;1(4), ISSN 1553-992X .

2. Adeyemi, T.O. (2007). Research methods and thesis writing in educational studies. Lagos. New Heaven publishers, pp:160-151.

3. Adeniran, R.C. (1997) "A schema-theoretic view of basic processes in reading comprehension", in Carrell, P.L.

4. Aremu, E.O. (2002). Comparative study of the reading habit of boarding and day secondary school students in Osogbo, Nigeria. Pakistan journal of social sciences. 4(4): 506-512.

5. Bard, N. (2011). In-put out formation on academic achievement of a learner. USA: Maxwell publisher.

6. Collins, M and Cheek, E. (1999). Assessing and guiding reading instruction. New York McGraw Hill.

7. Douglas, M.P. (2000). Primary school library and its services. Paris UNESCO. 
8. Federal Republic of Nigeria (2004). National Policy education Lagos. Federal government press.

9. Federal Republic of Nigeria (2013). National policy on education Lagos. Federal government press.

10. Okebukola, P.A.D. (2004). Reading: "Key to lifelong development." A key note address delivered at the workshop on readership promotion campaign organized by the national library of Nigeria pp. 112.

11. Onipede, H. (2003). National development hinges on quality education. The Comet. Thursday 2 nd January, pp:21.

12. Oyeniyi, M. P. (2010). Teaching library skills and the effective use of books and libraries. The teacher librarian,49, (pp 2-7).

13. Sokan, J.D. (2002). Assessing and guiding reading instruction. New York. McGraw Hill. 